\title{
Changes in the Activity of Digestive Enzymes Produced from the Gut Microflora of Silkworm Bombyx mori L. (Lepidoptera: Bombycidae) in Response to Fortification of Mulberry Leaves
}

\author{
N. Mala ${ }^{1^{*}}$ and K. Vijila ${ }^{2}$ \\ ${ }^{1}$ Department of Sericulture, FC \& RI, TNAU, Mettupalayam, Tamil Nadu, India \\ ${ }^{2}$ Directorate of Open and Distance Learning, TNAU, Coimbatore, Tamil Nadu, India \\ *Corresponding author
}

\begin{tabular}{|c|c|}
\hline & A B S T R A C T \\
\hline & \multirow{6}{*}{$\begin{array}{l}\text { Gut micro-organisms have the ability to adapt themselves to changes in insect diet and the } \\
\text { enzyme activity fluctuates in response to dietary changes. A total of } 72 \text { dominant isolates } \\
\text { was successfully collected from the intestine of the fourth and fifth instar silkworm larvae } \\
\text { fed with fortified mulberry leaves. The isolates represented } 12 \text { phenotypical forms on } \\
\text { nutrient agar plates. Eleven phenotypes existed in the intestine of the larvae fed with } \\
\text { mulberry leaves supplemented with Aloe vera and Tinospora cordifolia and ten found in } \\
\text { larvae fed with only mulberry leaves. Ten of them were common in the intestine of three } \\
\text { groups. The total highest cultivable bacterial count found to be } 4.82 \pm 0.446 \times 10^{6} \text { and } 6.32 \\
\pm 0.269 \times 10^{6} \mathrm{CFU} / \mathrm{ml} \text { of } B \text {. mori larval digestive tract suspension of fourth and fifth instar } \\
\text { respectively. The results showed that the clearing zone and hydrolysis capacity value of } \\
\text { cellulose, starch and lipid degrading bacteria were found to be highest in treated groups } \\
\text { compared to control. The enzyme assay for cellulase, amylase and lipase activity was } \\
\text { found to be highest for BMGB } 42 \text { isolate with } 0.428,1.02 \text { and } 11.33 \text { (U/ml/min) } \\
\text { respectively. The results indicate that the diet had significant impact on the gut bacterial } \\
\text { community and enzyme activity. It was also observed that there was a proportional } \\
\text { increase in the total bacterial count as well as percent dominance of cellulase, amylase and } \\
\text { lipase with respect to the growth of } B \text {. mori. }\end{array}$} \\
\hline Keywords & \\
\hline $\begin{array}{l}\text { Digestive enzymes, } \\
\text { Gut microflora, } \\
\text { Fortification, } \\
\text { Silkworm. }\end{array}$ & \\
\hline Article Info & \\
\hline $\begin{array}{l}\text { Accepted: } \\
\text { 04 September } 2017 \\
\text { Available Online: } \\
10 \text { November } 2017\end{array}$ & \\
\hline & \\
\hline
\end{tabular}

\section{Introduction}

The Bombyx mori L. is an important economic sericigenous insect which feeds mainly on mulberry leaf and convert leaf protein into silk protein (Babu et al., 2009). In silkworm, majority of the characters that contribute to the yield of silk are under the control of polygenic nature (Seshagiri et al., 2009; Konate et al., 2011). The factors responsible to influence the growth, development and subsequent physiology of insect body include: nutritional qualities of food, biochemical status of nutrients in the food, hormonal level in the body and environmental conditions (Murugan and George, 1992). The leaves of mulberry are the sole source of food for larval instars of silkworm, Bombyx mori (L), biochemically constituted with proteins, lipids, carbohydrates and minerals (Subramanyam, 1992). Therefore, the corresponding diversity of enzymes capable of hydrolyzing the biocompounds of mulberry is exhibited by gut 
of larval instars of silkworm, Bombyx mori (L). Enzymes play a vital role in the metabolism of dietary food in the body of an organism. In silkworm, the digestive enzymes in the gut breakdown the complex form of nutrients present in the food into simpler forms. These simpler forms are easily absorbed into the body through the semi permeable membrane of alimentary canal.

Gut micro-organisms have the ability to adapt themselves to changes in insect diet, by induction of enzymes or by population changes in the microbial community, where the enzyme activity fluctuates in response to dietary changes (Kaufman and Klug, 1991; Santo Domingo et al., 1998). Scientists have tried alternative food for the rearing of silkworms which are of cost effective. The activity of the amylase, sucrase, and protease were increased on Dolichos lablab supplementation to silkworm and it is presumed that the bean might have activated the enzyme molecules to act on their substrates (Manjula et al., 2010). The fibroin content of the cocoon shell significantly increased in response to the dietary supplementation of botanicals. Javed and Gondal have also reported that silkworm fed with nitrogen and ascorbic acid supplemented mulberry leaves showed higher growth and lower mortality.

Treating the mulberry leaves with herbal drug: kho-go and feeding them to fifth instar larvae was found reflected into significant improvement in the levels of proteins and velocities of biochemical reactions catalyzed by protease and amylase (Khyade Vitthalrao and Doshi Sucheta, 2012).

The efforts towards the qualitative silk production through the improvement in the efficiency of consumption and utilization of food by larval instars of silkworm, Bombyx mori (L) include: improvement in the quality of mulberry leaves and fortify the leaves with nutrients, antibiotics, juvenile hormones, dusting with botanicals or extrafoliation of mulberry leaf with sugars, vertebrate hormones, feed additives, protein rich flours etc. The present study was aimed to understand the changes in the digestive physiology by analyzing the activities of the digestive enzymes when supplemented with the mulberry leaves fortified with plant extracts.

\section{Materials and Methods}

The experiments were conducted in the Microbiology laboratory, Forest College and Research Institute, Mettupalayam which is located at an altitude of 300 meters MSL, 77.56' E latitude and 11.19' N longitude.

\section{Rearing of silkworm with the mulberry leaves fortified with plant extracts}

The disease free laying (DFLs) of double hybrid race (CSR6 x CSR26) x (CSR2 x CSR27) were procured from Silkworm Seed Production Centre, Coimbatore. The larvae were reared from first to fifth instar under hygienic conditions with optimum temperature $\left(25-28^{\circ} \mathrm{C}\right)$ and relative humidity (75-85\%) in rearing room (Krishnaswami, 1978).

The mulberry leaves of V1 variety were fed 3-4 times a day from first to third instar and were divided into three groups; one group reared with mulberry leaves fortified with Tinospora cordifloia at 2 per cent concentration, the second group on mulberry leaves fortified with Aloe vera $100 \%$ pure gel extract and the third group reared with only mulberry leaves and served as control. The treatment was given for the first feed of $4^{\text {th }}$ and $5^{\text {th }}$ instar and once during fifth mid instar ( $4^{\text {th }}$ day). The remaining feed was given only with mulberry leaves. 
Isolation and enumeration of gut microflora

The $4^{\text {th }}$ instar larvae prior to change to the next instar and 3 days old $5^{\text {th }}$ instar larvae were used in the experiment and subjected to starvation for 24 hours. Subsequently, the larvae were anesthetized with chloroform soaked cotton pads and surface sterilized by submersion into $75 \%$ ethanol for one minute and rinsed three times using sterile distilled water prior to dissection. The larvae were dissected in a UV laminar flow hood using dissection scissors and the entire alimentary canal of individual larva was aseptically separated using sterilized fine-tipped forceps. The isolated digestive tract was washed with sterile ice-cold saline $(0.9$ per cent $\mathrm{NaCl})$ solution, chopped with a sterile blade, homogenized and incubated for 30 minutes at $37^{\circ} \mathrm{C}$. The supernatant was taken and serially diluted 1000 to 10,000 times.

The pour plate method was used to estimate total bacterial count on nutrient agar plates. The total viable count of cultivable total bacteria was expressed as the number of $\mathrm{CFU}$ in $1 \mathrm{ml}$ of sample.

\section{Isolation and screening of cellulase producing bacteria}

The isolated gut bacterial colonies where inoculated on Berg's minimal agar (Berg's et al., 1972) plate with $0.1 \%$ carboxy methyl cellulose (CMC) as substrate and incubated at $30^{\circ} \mathrm{C}$ for 24 to 48 hours. Colonies showing degradation capacity was identified using Congo red overlay method according to Bergey's manual of systemic bacteriology (Sneath et al., 1984). For the Congo red method, plates were flooded with $0.1 \%$ aqueous Congo red for 30 minutes with intermittent shaking and destain with $1 \mathrm{M}$ $\mathrm{NaCl}$ solution. A clearing zone around the colony indicates the hydrolysis of cellulose
(Wood 1980). Cellulose-degrading potential of the positive isolates was also qualitatively estimated by calculating hydrolysis capacity (HC), that is, the ratio of diameter of clearing zone and colony (Hendricks et al., 1995)

\section{Isolation and screening of amylase producing bacteria}

The gut bacterial isolates were screened for producing amylolytic activity by starch hydrolysis test on Berg's minimal agar (Berg's et al.,1972) plate with $1 \%$ starch as substrate and incubated at $30^{\circ} \mathrm{C}$ for 24 hours. Colonies showing degradation capacity was assayed by plate screening using the iodine method according to Bergey's manual of systemic Bacteriology (Sneath et al., 1984). For the iodine method starch plates were flooded with iodine solution resulting in dark blue plates with uncoloured zones where the starch had been degraded (Hols et al., 1994). Starch degrading potential of the positive isolates was also qualitatively estimated as reported by Hendricks et al., 1995.

\section{Isolation and screening of lipase producing bacteria}

The isolated bacterial colonies were inoculated on Rhodamine B agar plate containing $12 \%$ olive oil emulsion as substrate and incubated at $30^{\circ} \mathrm{C}$ for 24 to 48 hours (Feng et al., 2011). Lipase production was observed as a pink zone of hydrolysis around the bacterial colony. Lipid degrading potential of the positive isolates was also qualitatively estimated as reported by Hendricks et al., 1995.

\section{Assays for enzyme activity}

The gut bacterial isolates which are positive for all three enzyme activities viz., cellulase, amylase and lipase are only considered for assay studies. 


\section{Cellulase assay}

Endoglucanase (1, 4- $\beta$ endoglucanase - EC 3.2.1.4) activity was assayed by measuring the amount of reducing sugar from carboxy methyl cellulose using 3, 5- dinitrosalicylic acid. The enzyme activity was determined according to the methods recommended by the International Union of Pure and Applied Chemistry (IUPAC) commission on biotechnology (Ghose, 1987). The One unit $(\mathrm{U} / \mathrm{mL})$ of enzymatic activity is defined as the amount of enzyme that releases $1 \mu \mathrm{mol}$ of reducing sugar (measured as glucose) per $\mathrm{mL}$ per minute under the assay conditions. All the tests were conducted in triplicates and mean activities were determined.

\section{Amylase activity}

The enzyme activity was assayed following the method of Bernfeld (1955) using 3, 5dinitrosalicylic acid. The substrate used for studying $\alpha$-amylase (EC 3.2.1.10) was 1\% starch. The One unit of enzymatic activity is defined as the amount of enzyme that releases $1 \mu \mathrm{mol}$ of maltose per $\mathrm{mL}$ per minute under the assay conditions.

\section{Lipase assay (Titrimetric method)}

The lipase activity was assayed using the method of Yadav et al., (1993). One unit (U) of lipase activity was defined as the amount of enzyme which produces $1 \mu \mathrm{mol}$ of fatty acids per minute under assay conditions.

\section{Results and Discussion}

\section{Bacterial isolates from the digestive tract of Bombyx mori L. with fortified mulberry leaves}

Gut micro-organisms have the ability to adapt themselves to changes in insect diet, by induction of enzymes or by population changes in the microbial community. In the present study, a total of 72 dominant isolates was successfully collected from the intestine of the fourth and fifth instar silkworm larvae fed with fortified mulberry leaves. The isolates represented 12 phenotypical forms on nutrient agar plates. Eleven phenotypes existed in the intestine of the larvae fed with mulberry leaves supplemented with Aloe vera and Tinospora cordifolia and ten found in larvae fed with only mulberry leaves. Ten of them were common in the intestine of three groups. The total highest cultivable bacterial count found to be $4.82 \pm 0.446 \times 10^{6}$ and 6.32 $\pm 0.269 \times 10^{6} \mathrm{CFU} / \mathrm{ml}$ of $B$. mori larval digestive tract suspension of fourth and fifth instar respectively (Table 1). Aloe vera fed silkworm expressed the presence of highest number of population. The main feature of the Aloe vera plant is its high water content, ranging from $99 \%$ to $99.5 \%$, while the remaining $0.5-1.0 \%$ solid material is reported to contain over 200 different potentially active compounds, including vitamins, minerals, enzymes, simple and complex polysaccharides, phenolic compounds, and organic acids (Boudreau et al., 2013a; Rodriguez et al., 2010). It was also observed that there is a proportional increase in the total bacterial count with respect to the growth of B. mori. Some of the plant products contain insect juvenoids (like engenol) which are known to increase the capability of consumption and utilization of food by insects like silkworm. Administration of botanicals to silkworm help in supplementation of various biochemical constituents (Amino acid, proteins, alkaloids, glucoside, phyllanthine, psoralen, betasitosterol) which have the property of phagostimulants and attractants was reported in mulberry (Manoharan, 1996). In phytophagous insects, the exogeneous compounds through herbal feed mimic the action of natural juvenile hormone, which enhance the synthesis of poly (A) RNA for major silk protein (Khyade Vitthalrao and 
Doshi Sucheta, 2012). Feng et al., 2011 reported the diversity of bacteria from the intestine of silkworm fed on tricuspid cudrania leaves and mulberry leaves. The lipase producing bacterial community likely shows great changes in response to the food source. Diet is also known to influence the intestinal microorganism community in cockroaches and crickets, where microbial populations fluctuate in response to dietary changes (Kane and Breznak, 1991; Santo Domingo et al., 1998). This appears to the case in other lepidopteran caterpillars such as the gypsy moth, with 15 phylotypes at its most complex and 7 phylotypes at its simplest (Broderick et al., 2004).

\section{Hydrolytic capacity of bacterial isolates utilizing cellulose, starch and lipid from the digestive tract of B.mori.}

In insects, the complex food molecules are utilized after they have been processed into simpler molecules through the action of digestive enzymes in the gut of the larva. Thus the enzyme system in the silkworm plays a vital role in determining the performance of the larva in terms of effective transformation of organic food molecules of the leaf into useful biomolecules. So in this study, the 72 isolates obtained from silkworm gut fed with different plant extracts were subjected to screening for enzyme production and their respective hydrolytic activity. The results showed that the clearing zone and hydrolysis capacity value of cellulose degrading bacteria ranged between 11.0 to $39.0 \mathrm{~mm}$ and 1.80 to 2.03 for Aloe vera treated group, 10.0 to $37.0 \mathrm{~mm}$ and 1.33 to 2.05 for Tinospora cordifolia treated group and 10.0 to $27.0 \mathrm{~mm}$ and 1.56 to 1.98 for mulberry control group (Table 2). The clearing zone and hydrolysis capacity value of starch degrading bacteria ranged between 12.0 to $55.0 \mathrm{~mm}$ and 1.20 to 2.14 for Aloe vera treated group, 10.0 to $48.0 \mathrm{~mm}$ and 1.38 to 2.06 for Tinospora cordifolia treated group and 14.0 to $42.0 \mathrm{~mm}$ and 1.38 to 2.08 for mulberry control group (Table 3 ).

The formation of pink zone and hydrolysis capacity value of lipid degrading bacteria ranged between 9.0 to $37.0 \mathrm{~mm}$ and 1.01 to 1.59 for Aloe vera treated group, 10.0 to 29.0 $\mathrm{mm}$ and 1.03 to 1.30 for Tinospora cordifolia treated group and 8.0 to $30.0 \mathrm{~mm}$ and 1.03 to 1.29 for mulberry control group (Table 4). The hydrolytic value found between 1.38 to 2.33 and 0.15 to 1.37 for cellulolytic aerobic bacterial isolates from farming and forest soil, respectively (Hatami et al., 2008). The clearing zone and $\mathrm{HC}$ value ranged between 28.0 to $50.0 \mathrm{~mm}$ and 4.3 to 9.0 for cellulose feeding organisms like termite, caterpillar, bookworm, and snail (Gupta et al., 2011). The Suseela et al., (2014) reported the lipase activity of fungal isolates ranged between 25.0 to $40 \mathrm{~mm}$ by cup plate method.

Table.1 Population of total cultivable bacteria from the digestive tract of Bombyx mori L. with fortified mulberry leaves

\begin{tabular}{|c|c|c|}
\hline \multirow{2}{*}{ Group } & \multicolumn{2}{|c|}{ Total viable population of bacteria (CFU/ml) } \\
\hline & IV instar & V instar \\
\hline Mulberry + Tinospora cordifolia & $4.34( \pm 0.386)^{b}$ & $5.12( \pm 0.303)^{b}$ \\
\hline Mulberry+ Aloe vera & $4.82( \pm 0.446)^{\mathrm{a}}$ & $6.32( \pm 0.269)^{\mathrm{a}}$ \\
\hline Mulberry only (control) & $3.78( \pm 0.291)^{\mathrm{c}}$ & $4.48( \pm 0.333)^{\mathrm{c}}$ \\
\hline
\end{tabular}

Values are means \pm S.d. for each group. a-c Values not sharing a common superscript letter within each column differ significantly at $\mathrm{P}<0.05$. 
Table.2 Effect of fortification of mulberry leaves on maximum clearing zone and hydrolytic capacity (HC) of bacterial isolates from the gut of silkworm for cellulase production

\begin{tabular}{|c|c|c|c|c|c|c|c|c|}
\hline $\begin{array}{c}\begin{array}{c}\text { Isolates } \\
\text { from }\end{array} \\
\text { Mulberry + } \\
\text { T. Cordiflia }\end{array}$ & $\begin{array}{c}\text { Maximum } \\
\text { clearing } \\
\text { zone } \\
\text { (mm) }\end{array}$ & $\begin{array}{c}\text { HC } \\
\text { value }\end{array}$ & $\begin{array}{l}\text { Isolates } \\
\text { from } \\
\text { Mulberry } \\
+ \text { A. vera }\end{array}$ & $\begin{array}{c}\text { Maximum } \\
\text { clearing } \\
\text { zone } \\
\text { (mm) }\end{array}$ & $\begin{array}{c}\text { HC } \\
\text { value }\end{array}$ & $\begin{array}{l}\text { Isolates } \\
\text { from } \\
\text { Mulberry } \\
\text { control }\end{array}$ & $\begin{array}{c}\text { Maximum } \\
\text { clearing } \\
\text { zone } \\
\text { (mm) }\end{array}$ & $\begin{array}{c}\text { HC } \\
\text { value }\end{array}$ \\
\hline BMGB1 & 23 & 1.93 & BMGB25 & 20 & 1.96 & BMGB49 & 11 & 1.86 \\
\hline BMGB2 & 10 & 1.78 & BMGB26 & 15 & 1.87 & BMGB50 & - & - \\
\hline BMGB3 & 28 & 1.91 & BMGB27 & 19 & 1.88 & BMGB51 & - & - \\
\hline BMGB4 & 13 & 1.80 & BMGB28 & 13 & 1.85 & BMGB52 & 19 & 1.58 \\
\hline BMGB5 & 11 & 1.83 & BMGB29 & - & - & BMGB53 & - & - \\
\hline BMGB6 & 20 & 1.87 & BMGB30 & 28 & 1.93 & BMGB54 & 20 & 1.94 \\
\hline BMGB7 & - & - & BMGB31 & - & - & BMGB55 & - & - \\
\hline BMGB8 & - & - & BMGB32 & 11 & 1.83 & BMGB56 & - & - \\
\hline BMGB9 & - & - & BMGB33 & 14 & 1.86 & BMGB57 & - & - \\
\hline BMGB10 & 27 & 1.98 & BMGB34 & 15 & 1.87 & BMGB58 & - & - \\
\hline BMGB11 & - & - & BMGB35 & 21 & 1.92 & BMGB59 & 15 & 1.56 \\
\hline BMGB12 & 21 & 1.92 & BMGB36 & - & - & BMGB60 & 19 & 1.87 \\
\hline BMGB13 & 11 & 1.77 & BMGB37 & 12 & 1.84 & BMGB61 & 27 & 1.98 \\
\hline BMGB14 & 20 & 1.84 & BMGB38 & 35 & 2.00 & BMGB62 & - & - \\
\hline BMGB15 & - & - & BMGB39 & - & - & BMGB63 & - & - \\
\hline BMGB16 & 15 & 1.76 & BMGB40 & 22 & 1.91 & BMGB64 & 23 & 1.82 \\
\hline BMGB17 & 37 & 2.05 & BMGB41 & 20 & 1.80 & BMGB65 & 12 & 1.73 \\
\hline BMGB18 & 19 & 1.91 & BMGB42 & 39 & 2.03 & BMGB66 & 16 & 1.79 \\
\hline BMGB19 & 12 & 1.33 & BMGB43 & 24 & 1.93 & BMGB67 & 10 & 1.70 \\
\hline BMGB20 & - & - & BMGB44 & - & - & BMGB68 & 11 & 1.75 \\
\hline BMGB21 & 15 & 1.89 & BMGB45 & - & - & BMGB69 & 19 & 1.85 \\
\hline BMGB22 & - & - & BMGB46 & 16 & 1.88 & BMGB70 & - & - \\
\hline BMGB23 & - & - & BMGB47 & 18 & 1.93 & BMGB71 & - & - \\
\hline BMGB24 & - & - & BMGB48 & - & & BMGB72 & - & - \\
\hline
\end{tabular}


Table.3 Effect of fortification of mulberry leaves with plant extracts on maximum clearing zone and hydrolytic capacity (HC) value of bacterial isolates from the gut of silkworm for amylase production

\begin{tabular}{|c|c|c|c|c|c|c|c|c|}
\hline $\begin{array}{c}\text { Isolates } \\
\text { from } \\
\text { Mulberry + } \\
\text { T. } \text { Cordiflia }\end{array}$ & $\begin{array}{c}\text { Maximum } \\
\text { clearing } \\
\text { zone } \\
\text { (mm) }\end{array}$ & $\begin{array}{c}\text { HC } \\
\text { value }\end{array}$ & $\begin{array}{c}\text { Isolates } \\
\text { from } \\
\text { Mulberry } \\
\mathbf{+} \text {. vera }\end{array}$ & $\begin{array}{c}\text { Maximum } \\
\text { clearing } \\
\text { zone } \\
\text { (mm) }\end{array}$ & $\begin{array}{c}\text { HC } \\
\text { value }\end{array}$ & $\begin{array}{c}\text { Isolates } \\
\text { from } \\
\text { Mulberry } \\
\text { control }\end{array}$ & $\begin{array}{c}\text { Maximum } \\
\text { clearing } \\
\text { zone } \\
\text { (mm) }\end{array}$ & $\begin{array}{c}\text { HC } \\
\text { value }\end{array}$ \\
\hline BMGB1 & 27 & 1.90 & BMGB25 & 41 & 1.95 & BMGB49 & 39 & 1.95 \\
\hline BMGB2 & 12 & 1.71 & BMGB26 & - & - & BMGB50 & - & - \\
\hline BMGB3 & 40 & 1.88 & BMGB27 & - & - & BMGB51 & 14 & 1.76 \\
\hline BMGB4 & 10 & 1.38 & BMGB28 & 38 & 1.90 & BMGB52 & 40 & 2.02 \\
\hline BMGB5 & - & - & BMGB29 & 30 & 2.14 & BMGB53 & 36 & 2.03 \\
\hline BMGB6 & - & - & BMGB30 & 12 & 1.33 & BMGB54 & 38 & 1.92 \\
\hline BMGB7 & - & - & BMGB31 & - & - & BMGB55 & - & - \\
\hline BMGB8 & 15 & 1.87 & BMGB32 & 12 & 1.20 & BMGB56 & - & - \\
\hline BMGB9 & - & - & BMGB33 & 19 & 1.90 & BMGB57 & - & - \\
\hline BMGB10 & - & - & BMGB34 & 15 & 2.00 & BMGB58 & - & - \\
\hline BMGB11 & 37 & 2.05 & BMGB35 & 25 & 1.92 & BMGB59 & - & - \\
\hline BMGB12 & - & - & BMGB36 & - & - & BMGB60 & - & - \\
\hline BMGB13 & 15 & 1.89 & BMGB37 & - & - & BMGB61 & - & - \\
\hline BMGB14 & 10 & 1.88 & BMGB38 & - & - & BMGB62 & - & - \\
\hline BMGB15 & 11 & 1.80 & BMGB39 & 13 & 1.85 & BMGB63 & 15 & 1.38 \\
\hline BMGB16 & 19 & 1.72 & BMGB40 & - & - & BMGB64 & 42 & 1.94 \\
\hline BMGB17 & 48 & 1.95 & BMGB41 & - & - & BMGB65 & - & - \\
\hline BMGB18 & 16 & 1.79 & BMGB42 & 55 & 2.03 & BMGB66 & 19 & 1.79 \\
\hline BMGB19 & 38 & 2.06 & BMGB43 & 20 & 1.81 & BMGB67 & - & - \\
\hline BMGB20 & - & - & BMGB44 & 28 & 1.93 & BMGB68 & - & - \\
\hline BMGB21 & - & - & BMGB45 & - & - & BMGB69 & - & - \\
\hline BMGB22 & - & - & BMGB46 & 19 & 1.72 & BMGB70 & - & - \\
\hline BMGB23 & - & - & BMGB47 & - & - & BMGB71 & - & - \\
\hline BMGB24 & - & - & BMGB48 & 27 & 1.93 & BMGB72 & - & - \\
\hline$-=$ & & & & & & - \\
\hline
\end{tabular}


Table.4 Effect of fortification of mulberry leaves with plant extracts on maximum clearing zone and hydrolytic capacity $(\mathrm{HC})$ value of bacterial isolates from the gut of silkworm for lipase production

\begin{tabular}{|c|c|c|c|c|c|c|c|c|}
\hline $\begin{array}{c}\text { Isolates } \\
\text { from } \\
\text { Mulberry + } \\
\text { T. Cordiflia }\end{array}$ & $\begin{array}{c}\text { Maximum } \\
\text { clearing } \\
\text { zone } \\
(\mathbf{m m})\end{array}$ & $\begin{array}{c}\text { HC } \\
\text { value }\end{array}$ & $\begin{array}{c}\text { Isolates } \\
\text { from } \\
\text { Mulberry } \\
\boldsymbol{+} \text { A. vera }\end{array}$ & $\begin{array}{c}\text { Maximum } \\
\text { clearing } \\
\text { zone } \\
(\mathbf{m m})\end{array}$ & $\begin{array}{c}\text { HC } \\
\text { value }\end{array}$ & $\begin{array}{c}\text { Isolates } \\
\text { from } \\
\text { Mulberry } \\
\text { control }\end{array}$ & $\begin{array}{c}\text { Maximum } \\
\text { clearing } \\
\text { zone } \\
(\mathbf{m m})\end{array}$ & $\begin{array}{c}\text { HC } \\
\text { value }\end{array}$ \\
\hline BMGB1 & 21 & 1.30 & BMGB25 & 35 & 1.59 & BMGB49 & 28 & 1.04 \\
\hline BMGB2 & - & - & BMGB26 & 11 & 1.08 & BMGB50 & - & - \\
\hline BMGB3 & 27 & 1.04 & BMGB27 & 15 & 1.03 & BMGB51 & 21 & 1.18 \\
\hline BMGB4 & - & - & BMGB28 & 24 & 1.04 & BMGB52 & 30 & 1.29 \\
\hline BMGB5 & - & - & BMGB29 & - & - & BMGB53 & 29 & 1.20 \\
\hline BMGB6 & 11 & 1.12 & BMGB30 & 9 & 1.05 & BMGB54 & 8 & 1.09 \\
\hline BMGB7 & 29 & 1.25 & BMGB31 & 30 & 1.37 & BMGB55 & 23 & 1.17 \\
\hline BMGB8 & - & - & BMGB32 & 12 & 1.10 & BMGB56 & - & - \\
\hline BMGB9 & 10 & 1.08 & BMGB33 & 27 & 1.08 & BMGB57 & 20 & 1.12 \\
\hline BMGB10 & - & - & BMGB34 & 25 & 1.01 & BMGB58 & - & - \\
\hline BMGB11 & - & - & BMGB35 & 28 & 1.40 & BMGB59 & - & - \\
\hline BMGB12 & 10 & 1.15 & BMGB36 & - & - & BMGB60 & - & - \\
\hline BMGB13 & 20 & 1.18 & BMGB37 & - & - & BMGB61 & 10 & 1.05 \\
\hline BMGB14 & 12 & 1.09 & BMGB38 & 23 & 1.02 & BMGB62 & 18 & 1.17 \\
\hline BMGB15 & - & - & BMGB39 & - & - & BMGB63 & 25 & 1.08 \\
\hline BMGB16 & 19 & 1.07 & BMGB40 & 21 & 1.05 & BMGB64 & 29 & 1.12 \\
\hline BMGB17 & 20 & 1.20 & BMGB41 & 29 & 1.03 & BMGB65 & - & - \\
\hline BMGB18 & 23 & 1.15 & BMGB42 & 37 & 1.52 & BMGB66 & - & - \\
\hline BMGB19 & 28 & 1.27 & BMGB43 & 33 & 1.31 & BMGB67 & - & - \\
\hline BMGB20 & 14 & 1.13 & BMGB44 & 30 & 1.29 & BMGB68 & - & - \\
\hline BMGB21 & 10 & 1.03 & BMGB45 & 19 & 1.05 & BMGB69 & - & - \\
\hline BMGB22 & - & - & BMGB46 & 25 & 1.09 & BMGB70 & - & - \\
\hline BMGB23 & - & - & BMGB47 & - & - & BMGB71 & 20 & 1.03 \\
\hline BMGB24 & 15 & 1.10 & BMGB48 & - & - & BMGB72 & - & - \\
\hline
\end{tabular}

$$
\text { - = Negative for lipase production }
$$

Fig.1 Per cent dominance of digestive enzymes producing bacteria from the digestive tract of Bombyx mori L. with fortified mulberry leaves

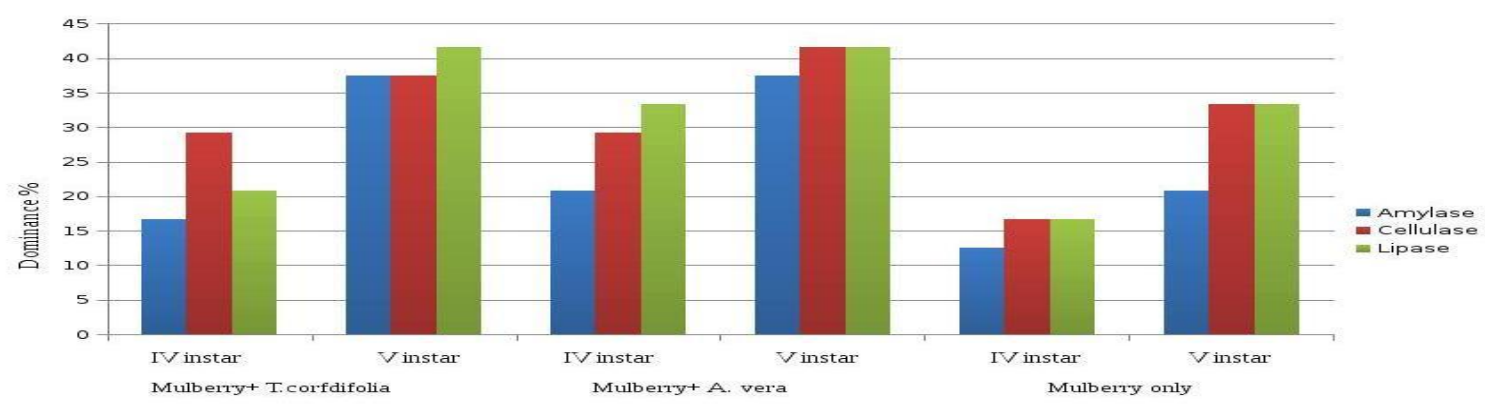


Fig.2 Cellulase and amylase activity of selective bacterial isolates

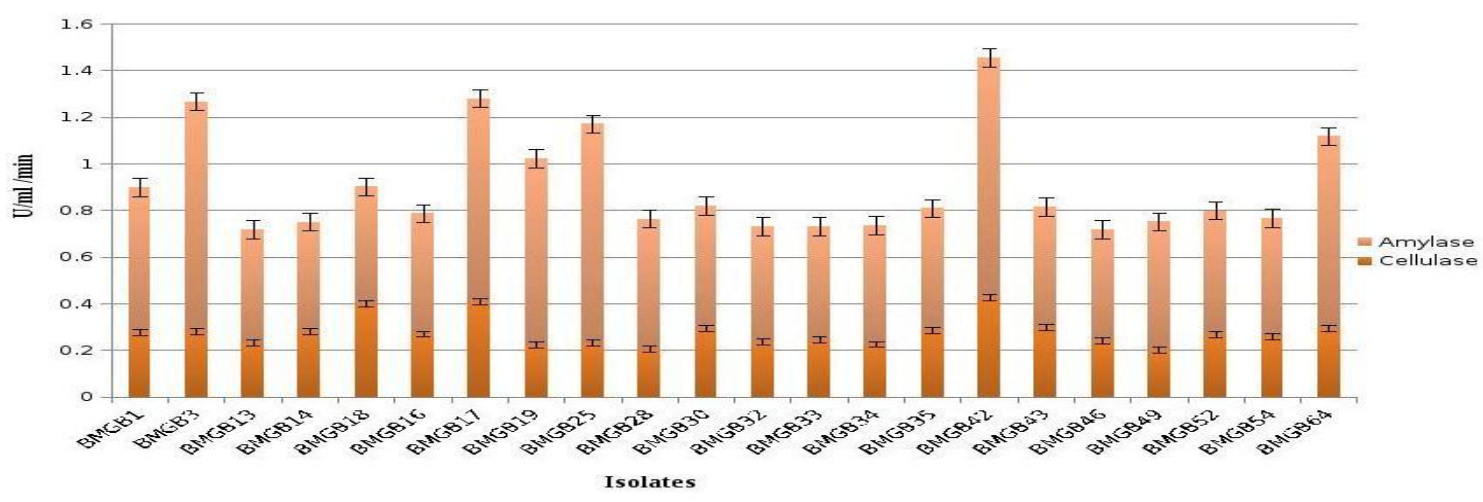

Fig.3 Lipase activity of selective bacterial isolates

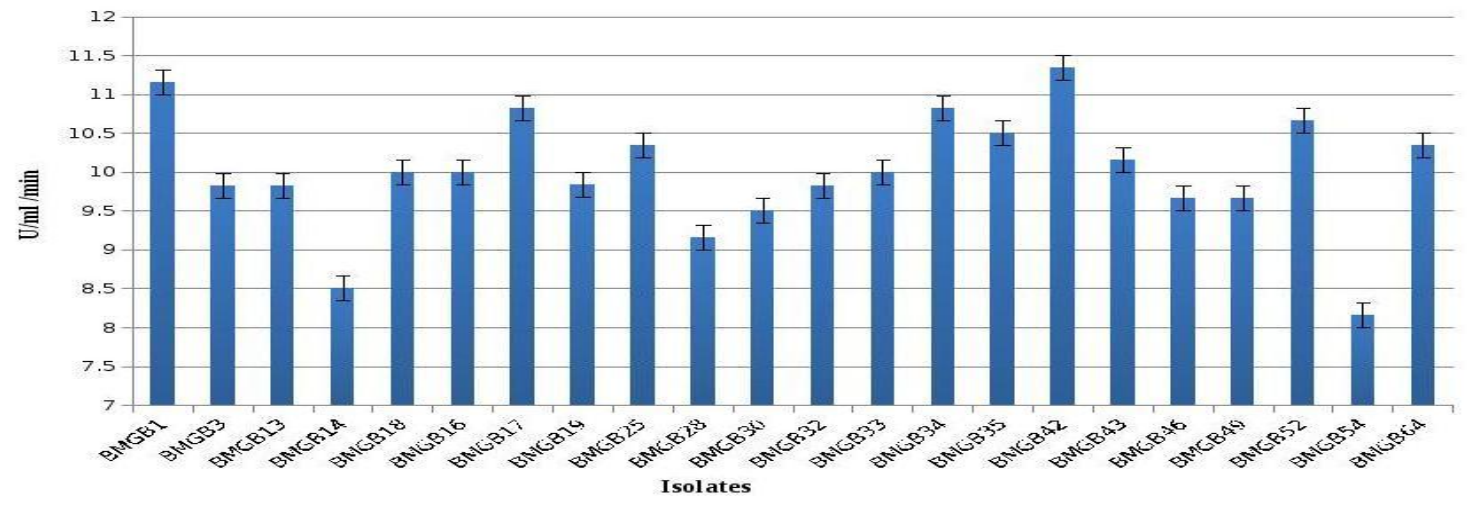

Of the isolates tested, 29.17 to 41.67 per cent of isolates were positive for cellulase production, 20.83 to 37.50 per cent of isolates were positive for amylase production and 33.33 to 41.67 per cent of isolates were positive for lipase production in the Aloe vera supplemented group (Fig. 1). However in the fifth instar, supplementation with Tinospora cordifolia also resulted in increased lipase producing bacteria in the gut and lowest positive isolates for cellulase, amylase and lipase were found in the control group fed only with mulberry leaves. It was found that there was a proportional increase in the percentage of cellulase, amylase and lipase producing bacteria from fourth to fifth instar larval gut system. The increase in these types of bacteria from fourth to fifth instar might be the reason for increased feed consumption.
The consumption of mulberry leaf during final instar accounts for more than $80 \%$ of the total consumption during its larval life and the leaves fed for fifth instar larvae are matured leaves rich in carbohydrate content (Kandylis et al., 2009). Food consumed in this stage is effectively utilized for the production of silk proteins as well as to support its metabolism (Lokesh et al., 2006). Thus the energy acquired by the larvae as a consequence of feeding is utilized in the subsequent nonfeeding stages. We also found that these cellulase, amylase and lipase producing bacteria are higher in the gut receiving plant products such as Aloe vera and Tinospora cordifolia along with mulberry leaves. The results are in line with Lokesh et al., (2012) reported that the digestive enzyme activity was found to be higher in fourth and fifth 
instar larvae fed with mulberry leaves supplemented with Diethyl Sulfate at $8 \mathrm{mM}$ dosage. The amylase, cellulase and $\beta$ glucosidase produced by the midgut of Tenebrio molitor larvae treated with antibiotics were high compared to non-treated controls (Genta et al., 2006).

\section{Enzyme activity of bacterial isolates from the digestive tract of Bombyx mori}

The isolates which are found to be positive for all three enzymes viz., cellulase, amylase and lipase production were only considered for enzyme assay studies. A total of 22 positive isolates were selected for enzyme activity. The cellulase and amylase enzyme activity level of the isolates obtained from the gut of silkworm fed with mulberry leaves supplemented with plant extracts at $\mathrm{pH} 7$ ranged from 0.202 to $0.428(\mathrm{U} / \mathrm{ml} / \mathrm{min})$ and 0.46 to $1.02(\mathrm{U} / \mathrm{ml} / \mathrm{min}$ ) respectively (Fig. 2$)$. The lipase enzyme activity level of the isolates ranged from 8.167 to 11.33 (U/ml/min) at $\mathrm{pH} 7$ (Fig. 3). The enzyme assay for cellulase, amylase and lipase activity was found to be highest for BMGB42 with $0.428,1.02$ and $11.33(\mathrm{U} / \mathrm{ml} / \mathrm{min})$ respectively with Aloe vera supplemented through mulberry leaves. Treating the mulberry leaves with herbal drug: kho-go and feeding them to fifth instar larvae was found reflected into significant improvement in the levels of proteins and velocities of biochemical reactions catalyzed by protease and amylase. The activities of mid gut protease and amylase were increased by 21.444 to 83.706 percent and 14.54 to 52.257 percent respectively over control (Khyade Vitthalrao and Doshi Sucheta, 2012). The mulberry leaves supplemented with nitrogenous compounds had a great influence on the amount of glucose in the larval hemolymph (Etebari et al., 2007). The amylase activity increased with increase in age during the fifth instar in EMS treated batches of silkworm with $1.1 \mathrm{mg} / \mathrm{g} / \mathrm{min}$ (Mahesha and Honnaiah, 2002).

From the present study it can be concluded that the fortification of mulberry leaves with plant extracts have an impact on improving physiological performances like enzyme activity in silkworms. Gut micro-organisms have the ability to adapt themselves to changes in insect diet, by induction of enzymes or by population changes in the microbial community. We suggest that bacteria from gut of the silkworm fed with mulberry leaves fortified with plant extracts provide digestive enzymes in a synergic manner and contribute to larval growth.

\section{References}

Babu, K. R., S. Ramakrishna, Y. H. K. Reddy, G. Lakshmi, N. V. Naidu, S. S. Basha and Bhaskar, M. 2009. Metabolic alterations and molecular mechanism in silkworm larvae during viral infection: A review. Afr. J. Biotechnol. 8, 899907.

Berg, B., B. V. Hofsten and Pettersson, G. 1972. Growth and cellulose formation by Cellvibrio fulvus. Journal of Applied Bacteriology. 35, 204-214.

Bernfeld, P., 1955. Week's citation classic: Amylases. Methods Enzymology. 1, 149-158.

Boudreau, M. D., F. A. Beland, J. A. Nichols and Pogribna, M. 2013a. Toxicology and carcinogenesis studies of a noncolorized whole leaf extract of Aloe barbadensis Miller (Aloe vera) in $\mathrm{F} 344 / \mathrm{N}$ rats and $\mathrm{B} 6 \mathrm{C} 3 \mathrm{~F} 1$ mice (drinking water study). Natl. Toxicol. Program Tech. Rep. Ser. 577,261-266.

Broderick, N. A., K. F. Raffa, R. M. Goodman and Handelsman, J. 2004. Census of the bacterial community of the gypsy moth larval midgut by using culturing and culture - independent 
methods. Applied and Environmental Microbiology. 70(1): 293-300.

Feng, W., X. Q. Wang, W. Zhou, G. Y. Liu and Wan, Y. J., 2011. Isolation and characterization of lipase-producing bacteria in the intestine of the silkworm, Bombyx mori, reared on different forage. Journal of Insect Science. 11, 135-140.

Genta, F. A., R. J., Dillon, W. R. Terra and Ferreira, C. 2006. Potential role for gut microbiota in cell wall digestion and glucoside detoxification in Tenebrio molitor larvae. Journal of Insect Physiology. 52, 593-601.

Ghose, T. K., 1987. Measurement of cellulase activity. Pure and applied chemistry. 59, 257-268.

Hatami, S., H. A. Alikhsni, H. Besharati, N. Salehrastin, M. Afrousheh and Jahromi, Z.Y. 2008. Investigation of aerobic cellulolytic bacteria in some of noeth forest and farming soils. The AmericanEurasian Journal of Agricultural \& Environmental Sciences. 5, 713-716.

Hendricks, C.W., J. D. Doyle and B. Hugley. 1995. A new solid medium for enumerating cellulose-utilizing bacteria in soil. Applied and Environmental Microbiology. 61(5): 2016-2019.

Hols, P., T. Ferain, D. Garmyn, N. Bernard and Delcour, J. 1994. Use of homologous expression-secretion signals and vector-free stable chromosomal integration in engineering of Lactobacillus plantarum for alphaamylase and levanase expression. Applied and Environmental Microbiology. 60(5): 1401-1413.

Javed, H., and Gondal, M. H. 2002. Effect of food supplementation by $\mathrm{N}$ and Ascorbic Acid on larval mortality of silkworm (Bombyx mori L). Asian journal of plant science. 1(5): 556-557.

Kandylis, K., I. Hadjigeorgiou and Harizanis, P. 2009. The nutritive value of mulberry leaves (Morus alba) as a feed supplement for sheep. The Animal Health Production. 41, 17-24.

Kane, M. D., and Breznak, J. A. 1991. Effect of host diet on production of organic acids and methane by cockroach gut bacteria. Applied and Environmental Microbiology. 57(9): 2628- 2634.

Kaufman, M. G., and Klug, M. J. 1991. The contribution of hindgut bacteria to dietary carbohydrate utilization by crickets (Orthoptera, Gryllidae). Comparative Biochemistry and Physiology. 98, 117-123.

Kayvan Etebari, Rahim Ebadi and Leila Matindoost. 2007. Physiological Changes of Silkworm (Bombyx mori L.) Larvae Fed on Mulberry Leaves Supplemented with Nitrogenous Compounds. J. Ent. Res. Soc. 9(2): 115.

Khyade Vitthalrao and Doshi Sucheta, S. 2012. Protein contents and activity of enzymes in the mod gut homogenate of fifth instar larvae of silkworm, Bombyx mori (L) (Race: PM x CSR2) fed with herbal drug(Kho-go) treated mulberry leaves. Res. J. Recent Sci. 1(2): 49-55.

Konate, K., A. Souza, M. Lamidi, J. F. Djoba Siawaya, F. H. E. Mendene, J. MillogoRasolodimby and Nacoulma, O.G. 2011. Biological and toxicological effects of aqueous acetone extract of Cienfuegosia digitata Cav. (Malvaceae) in mice and rats. J. Pharmacol. Toxiol. 6, 149-157.

Krishnaswami, S., 1978. New technology of silkworm rearing. Bulletin no: 2. Central Seriultural Research and Training Institute, Mysore, India.

Lokesh, G., M. Narayanaswamy and Ananthanarayana, S.R. 2006. The effect of chemical mutagen on haemolymph proteins of silkworm, Bombyx mori L. (Lepidoptera: Bombicidae) in $\mathrm{F}_{1}$ stage. J. Applied Sci. Environ. Manage. 10, 
21-25.

Lokesh, G., S. R. Ananthanarayana and Yogananda Murthy, V.N. 2012. Changes in the activity of digestive enzymes in response to chemical mutagen diethyl sulfate in the silkworm Bombyx mori L. (Lepidoptera: Bombycidae). Asian Journal of Applied Sciences. 5(6): 431-437.

Mahesha, H.B., and Honnaiah, S. 2002. Amylase and succinate dehydrogenase activity levels in $\mathrm{F} 1$ progeny raised from ethyl methanesulfonate treated silkworm, Bombyx mori L. Indian J. Seric. 41 (1): 24-28.

Manjula, S., S. Sabhanayakam, V. Mathivanan and Saravanan, N. 2010. Studies on the changes in the activities of digestive enzymes in the midgut of silkworm Bombyx mori.(L). (Lepidoptera: Bombycidae) fed with mulberry leaves supplemented with Indian bean (Dolichos lablab). Int. J. Biol. Med. Res. 1(4): 168-171.

Manoharan, S., 1996. Evaluation of certain botanicals for the management of grasserie of Bombyx mori L. M.Sc. (Agri.) Thesis, TNAU, Coimbatore, India, p.78.

Murugan, K., and George, A. (Sr.). 1992. Feedings and nutritional influence on growth and reproduction of Daphnia near (L). Insect Physiol. 38, 961-969.

Rodriguez, E. R., J. D. Martin and Romero, C. D. 2010. Aloe vera as a functional ingredient in foods. Crit. Rev. Food. Sci. Nutr. 50(4): 305-326.

Santo Domingo, J.W., I. M. Kaufman, M. J.
Klug, W. E. Holben, D. Harris and Tiedje, J.M. 1998. Influence of diet on the structure and function of the bacterial hindgut community of crickets. Molecular Ecology. 7, 761767.

Seshagiri, S.V., C. Ramesha and Rao, C. G. P. 2009. Genetic manifestation of hybrid vigor in cross breeds of mulberry silkworm, Bombyx mori L. Int. J. Zol. Res. 5, 150-160.

Sneath, P. H. A., N. S. Nair, E. M. Sharpe and Holt, J. G. 1984. Bergeys Manual of Systemic Bacteriology. Williams and Wilkins, $1^{\text {st }}$ edition. 408-494.

Subramanyam Reddy, C., 1992. Studies on distribution of digestive enzymes in the digestive tract of silkworm, Bombyx mori (L), M.Phil. Dissertation, Sri Venkateshwara University, Tirupati, India.

Suseela, L., M. Anupama, B. Prudhvilal, T. V. Narasaiah and Naveena Lavanya Latha, J. 2014. Isolation and Characterization of lipase producing fungi from palm oil mill effluent obtained from Pedavegi, A.P., India. International Journal of Biological and Pharmaceutical Research, 5(7): 559565.

Wood, P. J. 1980. Specify in the interaction of direct dyes with polysaccharides. Carbohydrate Research.85, 271-287.

Yadav, R.P., Saxena, R.K., Guptha, R. and Davison, S. 1993. Lipase by Aspergillus and Penicillium species. Int. J. Food Microbiol. 19, 217-227.

\section{How to cite this article:}

Mala, N. and Vijila, K. 2017. Changes in the Activity of Digestive Enzymes Produced from the Gut Microflora of Silkworm Bombyx mori L. (Lepidoptera: Bombycidae) in Response to Fortification of Mulberry Leaves. Int.J.Curr.Microbiol.App.Sci. 6(11): 225-236. doi: https://doi.org/10.20546/ijcmas.2017.611.027 